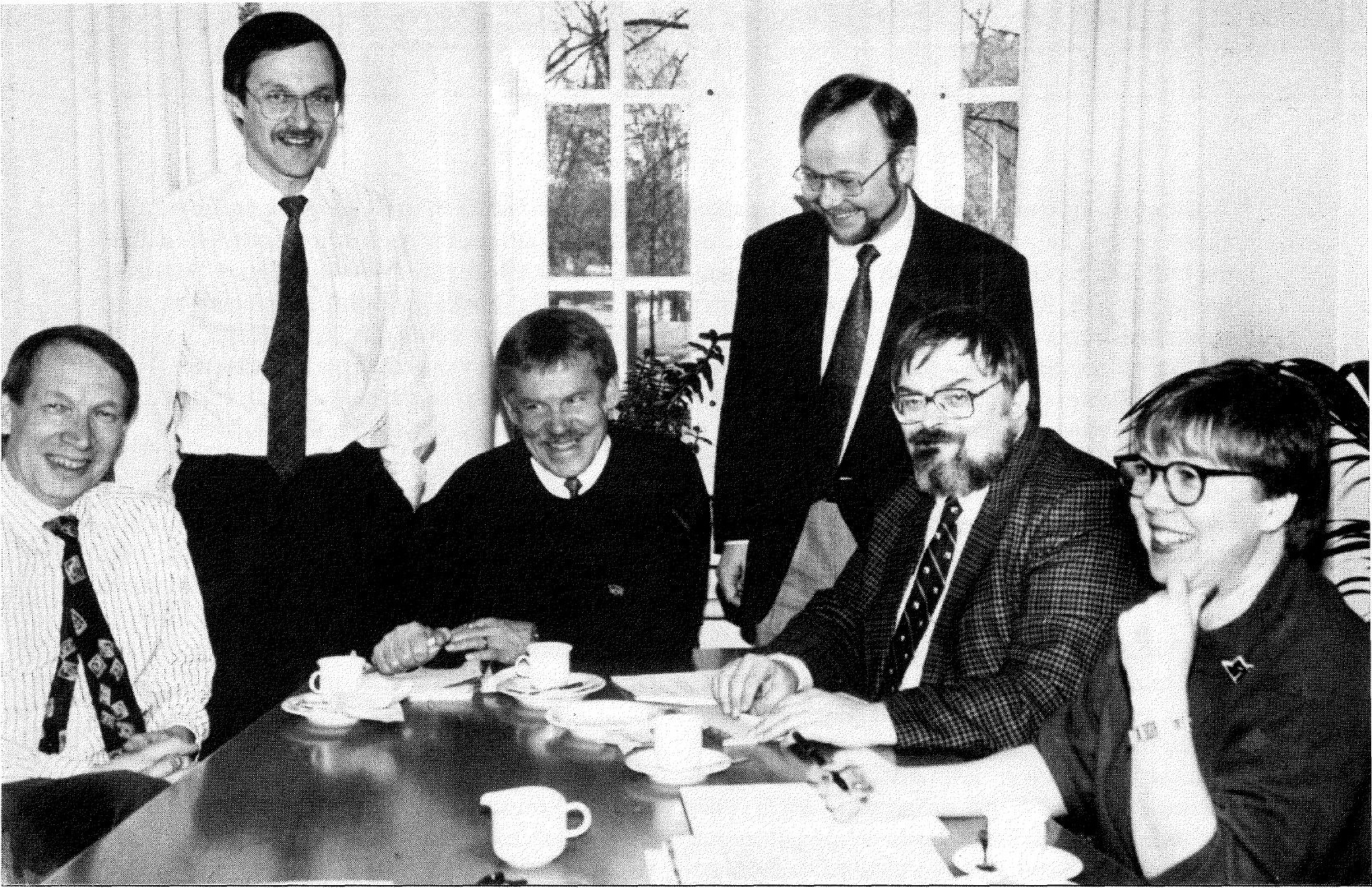

"Pyöreän pöydän" väki vasemmalta oikealle: Jyrki Haikonen, Kauko Hämäläinen, Pertti Tỉmonen, Simo Susiluoto, Urpo Kallio ja Tarja Koskela.

\title{
AIKUISKASVATUS TRENDIEN RISTIAALLOKOSSA
}

Mitkä ovat aikuiskasvatuksen kehityssuunnat, miten niihin suhtaudumme ja miten tietoisia ruorinpitäjiä koulutusruorissa itse olemme? Näistä kysymyksistä puhuttiin maaliskuun lopulla "pyöreässä pöydässä", johon osallistuivat johtaja Jyrki Haikonen Elinkeinoelämän valtuuskunnasta, johtava koulutuspäällikkö Tarja Koskela Kaupunkiliitosta, rehtori Pertti Timonen Tampereen työväenopistosta, rehtori Simo Susiluoto Keski-Uudenmaan ammatillisesta aikuiskoulutuskeskuksesta ja rehtori Urpo Kallio Virkailijain kansalaisopistosta, tämän vuoden ajan kuitenkin Helsingin yliopiston avoimesta korkeakoulusta.

Keskustelua johti Aikuiskasvatuslehden päätoimittaja Kauko Hämäläinen. Pitääkö paikkansa hänen yhteenvedossaan esittämänsä johtopäätös, että aikuiskoulutus tähtää menestymiseen, kansainvälisessä kilpailussa selviämiseen ja sen myötä koviin arvoihin? Tai se johtopäätös, että aikuiskoulutusorganisaatiot eivät ole tulevaisuuden rakentajia ja muokkaajia, vaan enemmänkin ne reagoivat yhteiskunnallisiin tilanteisiin? 
Willatsten lehityotrenthen keskella dhimme?

\section{JYRKI HAIKONEN}

Yritän kertoa näkemyksiäni siitä, mikä on muutoksen suunta. Koulutustahan on yritettävä rakentaa siihen maailmaan, johon Suomi on menossa.

\section{Näen sen kahdenlaisena.}

Ensiksikin riippumatta yhteiskunnan taloudellisesta tilasta jokaiseen ihmiseen ja yhteiskuntaan kokonaisuutena kohdistuvat vaatimukset muuttuvat kaiken aikaa. Ajatellaan vaikka sotien jälkeistä historiaa: 50-luvulla tehtiin terästä ja sementtiä, 60-luvulla alettiin rakentaa laivoja ja luotiin uutta metalliteollisuutta, 70-luvulla murtautui esiin elektroninen yhteiskunta, elektroniikkateollisuus ja muu vähän sofistikoidumpi teollisuus ja 80-luvulla tulivat elinkeinoelämään mukaan vakuutuslaitokset ja pankit. Ammatillisen koulutuksen vaatimukset ovat siis koko ajan muuttuneet.

Ehkä tulevaisuuden yhteiskunta on edellä kuvattujen kombinaatio. Mutta on muistettava, että nykyisen laman jälkeen työpaikat eivät palaa vanhoihin paikkoihinsa, vanhaan teollisuuteen, vaikka siellä vienti vetäisikin hyvin. Uudet työpaikat on luotava joko suurissa elektroniikkayrityksissä tai pienyrityksissä. Mutta kumpikaan niistä ei ole helppoa.

On helppo sanoa, että nyt on pienyritysten aika. Mutta kuinka moni pienyritys tekee konkurssin vuosi sen jälkeen, kun ... Pienyrityksetkään eivät siis takaa ratkaisua. Mutta tarvitsemme jatkuvasti ammattien erilaisuutta ja erikoistunutta koulutusta. Olemme joutuneet avoimeen maailmaan ja sen keskellä olemme tällaisia "kotikylän ihmisiä".

Toinen seikka on taloudellinen tilamme ja sen myötä korkea työttömyys. Ei voida enää nähdä työttömiä joukkona, joista pidetään hyväntahtoisesti taloudellisesti huolta tai joille annetaan vapaa-aika-, kulttuuri- ja aikuiskoulutuspalveluja ikään kuin viihteenomaisesti. Työttömät on nähtävä potentiaalisena joukkona ihmisiä, joilla osalla on korkea ammattitaito ja osalla koulutusta riittämättömästi. Tutkijat väittävät, että riittää vuosi kenelle tahansa meistä tätä työttömyyden statusta, niin pysyviä vaurioita alkaa syntyä.

\section{SIMO SUSILUOTO}

Mielestäni on näkyvissä kolme päätrendiä, jotka vaikuttavat nykyisessä aikuiskoulutuksessa.

Yksi on kansainvälistymisen trendi. Se näkyy milteipä kaikessa koulutuksessa. Toinen on taloudellisen kehityksen trendi, ja siihen liittyy valtionavun lasku ja koulutuksessa kilpailuttaminen. 1990-luvun alussa saamamme valtionapu väheni kerralla 30 prosenttiin. Loput piti hankkia myymällä koulutusta. Nyt valtionapu on 15 prosenttia ja loput pitää saada myymällä koulutusta työhallinnolle, yrityksille, kunnille jne. Kun ammattikoulumaisesta toiminnasta siirrytään kerralla liikeyritysmäiseen toimintaan, siinä on rankkaa trendiä kerrakseen.

Kolmas trendi on ihmisten yksilöllistyvät koulutusvaatimukset, ja siihen suuntaan kytkeytyvät aikuisdidaktiikan ja metodiikan kehittyminen, henkilökohtaiset opiskelusuunnitelmat, näyttökokeet ja tämän tyyppiset.

Nämä kolme peruselementtiä tulevat kaikki eri suunnista ja yhdessä ne synnyttävät ristiaallokon, jossa aikuiskasvatus on nykyään.

\section{JYRKI HAIKONEN}

Vaikka aikuiskoulutus sanana on ulkopuolisesta kummallinen, huonosti avautuva ammattialan sana, sillä asialla on yhä enemmän merkitystä, että me joudumme kouluttautumaan aikuisina yhä enemmän.

Mikä on se maailma, mihin aikuiskoulutus ihmisiä valmistaa? Siinä on olennainen kysymys. Yhteiskunnassahan on tehty merkittäviä väärinarviointeja ja tulevaisuutta on ennustettu vikaan monissa isoissakin asioissa: ekologia, kommunismi, Venäjä/ Neuvostoliitto. On siis suuria asioita, joita emme olleet lainkaan valmistautuneet. Olisiko mahdollista tarkastella maailmaa luovemmin ja konkreettisemmin ja tehdä oikeita suuntavalintoja? 
Whin koulutuksen twilsi py thie

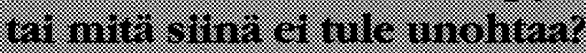

\section{SIMO SUSILUOTO}

Jos tarkastellaan elinkeinoelämän kehitystä, niin varmaa on ainakin se, että tuottavuuden kasvuvaatimus säilyy - tai tuottavuuden kasvattamisen vaatimus. Se asettaa ilman muuta melkoiset paineet myös sille, miten koulutusta lähestytään. Toinen on jo nyt Keski-Euroopassa näkyvissä oleva muutos: koulutukseen osallistuvien määrä lisääntyy, mutta koulutusjaksot lyhenevät.

Yleissivistävä ja ammatillinen aikuiskoulutus, jotka nyt erotetaan niin voimakkaasti toisistaan, pakostakin lähenevät. Niistä löytyy yhteinen elementti koulutuksen tehokkuuden lisäämiseksi.

Kun, Jyrki, puhuit koulutuksen ohjaamisesta kohti tulevaisuutta, on se ihan totta. Julkishallinto on kuitenkin ottanut ihan eri linjan: koulutus ohjataan lyhyellä tähtäimellä, markkinavoimien hetkellisten ratkaisujen mukaan. Suunnittelua ohjaa koulutuksen tuottama hetkellinen hyöty. Pitkäjänteinen suunnittelu uhrataan koulutuksen tehokkuuden alttarille.

Mitä tällainen pitkäjänteisyys merkitsisi? Esimerkiksi ihmisten valmiutta sopeutua muutoksiin, monialaisuutta, tällaisia yleisempiä avuja.

\section{PERTTI TIMONEN}

Meidät pitäisi kasvattaa muutoksiin. Suomalainenhan pelkää kaikkia muutoksia. Emme ole palvelukykyisiä ja palvelualttiita. Meissä on slaavilaista luonnetta ja siksi Suomi on puuhasteluyhteiskunta. Meille sopii puuhastelu, mutteivät selvät tavoitteet ja suoritukset.

Ja auta armias, yhteistyö! Onneksi emme tässä keskustelussa ole vielä kajonneet siihen!

\section{TARJA KOSKELA}

Kun joudumme kansainvälisiin kehiin, sosiaalisen osaamisen alueilla juuri olemme heikkoja. Mutta miksei niitä otetaan yhtä tiukasti esiin kuin kysymys siitä, osaammeko keittää sel- luloosaa? Heikkoutemme on yhteistyössä ja tiedonvaihdossa. Meidät on opetettu tietämään yksin, osaamaan yksin, kilpailemaan yksin. Ja sitten yhtäkkiä vaihto onkin tärkeä asia: tietojen, taitojen ja tunteiden vaihto. Ja yhteistyö. Eivät nämä ole minusta pehmeitä arvoja, vaan aika kovan osaamisen aluetta.

Tai ajatellaanpa vaatimattomuutemme ylikorostusta, semmoista "mitäpä meikäläinen" -henkeä. Meidän tulee ajatella kuten tapaamani englantilaiset pikkulapset: "as good as anybody".

\section{KAUKO HÄMÄLÄINEN}

Kun vertaa suomalaisia suurten kansakuntien edustajiin, esimerkiksi ranskalaisiin, jotka ovat herroja joka puolella missä liikkuvatkin, niin kyllä kai me pystymme lähestymään muita ihmisiä tasaveroisemmin. Se on mielestäni ihan myönteinen puoli suomalaisuudessa. Se mahdollistaa esimerkiksi kansainvälisessä kaupankäynnissä luontevuuden sen turhan keikaroinnin vastapainona, mitä monet muut kansat harrastavat. Eivät kaikki piirteemme ihan niin kehnoja ole.

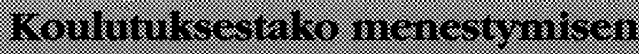 s.t. 1306}

\section{SIMO SUSILUOTO}

Kun ammatillisella puolella tarkastelee opiskelijoiden henkilökohtaisia saavutuksia, niin täytyy sanoa, että koulutus on aika kova juttu. Se on kohinaa, kun joukko ihmisiä, jotka ovat työttömiä ja joilla on yritysidea, opiskelevat yrityksen muodostamista kursseillamme. Kurssin aikana he sitten muodostavat yrityksensä asiantuntijan avulla, työllistyvät omaan yritykseensä ja työllistävät joukon muita. Tämäntapaisissa tilanteissa mulla on vankka usko koulutukseen.

\section{URPO KALLIO}

Koulutusta on alettu vihdoin arvioimaan panosten sijasta tuotoksilla. Ei siis enää kysellä aivan oikein - kuinka paljon olet istunut jossain tunneilla, kursseilla, suorittanut osioita, vaan mitä osaat. Silti väittäisin, että yksilöllisyyttä ja 
joustavuutta on meidän koulutusjärjestelmässämme liian vähän. Ne ensiaskeleet, joita otetaan monimuoto-opetuksessa, on suuntana aivan hyvä.

\section{JYRKI HAIKONEN}

On itsestään selvä asia, että lapsena tai nuorena saatu koulutus ei riitä aikuisiässä. Kysymys on siitä, onko yhteiskunnassa olemassa paikkoja, joissa voi ladata ja hankkia uutta ammattitaitoa. Onko ne riittävän selkeitä mulle? Jos niiden koulutus on liian yleistä, ei sillä kohta ole mitään merkitystä. Vain minä olen minä ja minulla on minun ongelmani, henkiset ongelmani, aineelliset ongelmani, palkkaongelmani... Haluan yksilöllisesti orientoitua tähän maailmaan... Minusta on itsestään selvää, että aikuiskoulutus on välttämätöntä ja sille on tärkeä paikka elämässä.

\section{URPO KALLIO}

Minusta koulutuksen tulisi vastata nimenomaan koulutuksen tarvitsijan odotuksiin, niihin yksilöllisiin odotuksiin, joita kullakin on. Luulen nimittäin, että jossakin vaiheessa on pakko pohtia sellaistakin kuin motivaatio.

Toinen seikka on mielestäni koulutuksen vaikuttavuus. Uskon, että jatkossa nimenomaan laatukriteereihin, vaikuttavuuteen, ylipäänsä koulutuksen tuloksellisuuteen ja tehokkuuteen ja sitä kautta miksei taloudellisuuteenkin kiinnitetään entistä enemmän huomiota.

Mutta en todellakaan usko, että jotkut ulkoatai ylhäältäpäin määritellyt aikuiskasvatuksen arvot vetäisivät ihmisiä koulutuksen piiriin. Ratkaisevia ovat koulutettavan tarpeet - ei kä yksin koulutettavan, vaan työnantajan myös. Hänkin on koulutuksen tarvitsija, omalle väelleen.

\section{TARJA KOSKELA}

Mika Mannermaa, mainio mies ajattelijaksi, sanoi kerran, että meidän tulee oppia ajattelemaan vähemmistöjen enemmistöä. Tähän liittyy minunkin "kansalainen toimijana" -ajattelu. Vähemmistöjen enemmistöt ovat minunkin mielestäni tulossa aikuiskoulutuksen haasteeksi.

\section{Onko arvoilla sijaa \\ aikuiskasvatuksessa?}

\section{PERTTI TIMONEN}

Minua myös pikkuisen pännii sen sortin arvokeskustelu, että "kun ei käydä arvokeskustelua" ja "pitäis käydä arvokeskustelua". En usko sitäkään, että aikaisemmat arvot olisivat jotenkin olleet nykyisiä parempia tai eläisimme jotenkin arvotonta aikaa.

Edustamaani kansalais- ja työväenopistoliikkeeseen on aina niitattu arvo-odotuksia. Totta on, että wrightiläinen ja liberaali porvarillinen sivistysliike tähtäsi työväestön valistamiseen ja sivistämiseen. Mutta olisi siinä toinenkin ajatus: työväestö piti pelataan vallankumoukselta. Myöhemmin kansalaisopistoja on yritetty valjastaa milloin itsenäisyysaatteen, milloin ulkopolitiikan veturiksi. Aikuiskasvatus on siis tiukasti kiinni siinä, mitä yhteiskunnassa muuten tapahtuu.

\section{URPO KALLIO}

Mielestäni Pertin käyttämä sana opistoliike on menneisyyden sana, sillä liikkeestä, jolla on samat arvolähtökohdat ja yhteiset arvot, ei enää voida puhua. Uskoakseni jatkossa arvot eriytyvät yhä enemmän organisaatiokohtaisesti. Vanhoista hyvistä arvoista varmaan kuitenkin säilyy humanismi jonkinlaisena yhteisenä pohjana.

Meillä on siis tulevaisuudessa liikkeen sijasta eriytyneitä oppilaitoksia, joilla on oma tehtävänkuva, kenties paikallisista sivistystarpeista syntyvä. Ja puolueettomuus-arvo on korvautunut moniarvoisuudella.

\section{PERTTI TIMONEN}

Olen puhunut ja puhun edelleenkin laadun ja tulosten puolesta ja korostan, että oppilaitoksen tulee olla nimenomaan oppilaitos, myös opiston. Kaikenlainen puuhastelu "hus siitä"!

Kun koulutusta on aivan valtavasti saatavissa ja erilaisia laitoksia on nurkittain, limittäin ja lomittain, mikä on oman laitokseni valtti tässä kilpailutilanteessa? Se saattaa olla yhteisö, joka muodostuu. Yhteisö on laatua. 


\section{JYRKI HAIKONEN}

Kun olemme 70-luvulta alkaen puhuneet informaatioyhteiskunnasta, niin havaitaan, että se olikin liian tekninen termi, liian muodollinen ja kylmä. Vähintään yhtä suuressa määrin maailmamme on tunneyhteiskunta, esimerkkeinä vaikkapa etniset ristiriidat tai suhtautuminen ympäristökysymyksiin ja kehitysmaihin. Aikakaudessamme on sekä teknologian ja informaation yhteiskunta ja sen rinnalla hyvin inhimillinen, persoonallisten tunteiden ja joukkojen tunteiden yhteiskunta.

Toinen kysymys on sitten se, ettei 500000 työttömän tilanne ole kovinkaan hauska. On se huono organisaatio, jos osa sen jengistä miettii, miten tulee huomenna toimeen. Pääsääntöisesti ongelma on hoidettavissa talouden kautta. Mutta jos me jättäydymme vain talouden varaan emmekä ota kulttuuria ja henkisiä arvoja huomioon, myös taloudessa menee huonosti. Menestyvä talous tarvitsee kulttuuria ja arvoja, ihan niin kuin kulttuuri ja arvot tarvitsevat tervettä taloutta. Tässä Suomi on kohtalaisten valintojen edessä.

Kyllä arvoilla on loppujen lopuksi merkitystä. Mutta ensin pitää vain nähdä nämä kovat seikat. Pitää nähdä se, että elämme kilpailun ja taloudellisen kasvun maailmassa. Pitää nähdä, että vanhoilla elinkeinoelämän elementeillämme emme pärjää, vaan niihin pitää sisällyttää ekologiset kysymykset ja inhimilliset kysymykset. Meidän on oltava mukana, vaikka haluaisimme vetäytyä pois tästä pahasta maailmasta.

\section{KAUKO HÄMÄLÄINEN}

Koulutuksellinen tasa-arvohan on ollut yksi aikuiskasvatuksen hellimä arvo. Nykyään aikuiskoulutuspalvelut kasautuvat kuitenkin siten, että 20-30 prosenttia väestöstä käyttää pääosan aikuiskoulutuspalveluista. Jos maksuja korotetaan vastaamaan todellisia kustannuksia, pian aikuiskoulutusta käyttää kenties 10 prosenttia väestöstä. Jos tämä keskustelu olisi käyty 15-20 vuotta sitten, suurin osa ajasta olisi käytetty pohtimaan koulutuksen tasa-arvon näkökulmaa. Nyt emme ole keskustelleet siitä lainkaan.

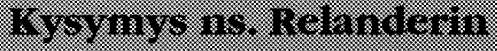

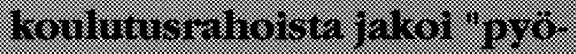

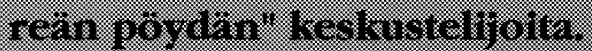
M116i perretedras

\section{PERTTI TIMONEN}

On aika hullua, että "normaalia" koulutusta ajetaan voimakkaasti alas ja sitten heitellään näitä Relanderin rahoja niin kuin luita ja sanotaan, että kilpailkaapa niistä. Koulutuslaitokset keksivät sitten hirveällä hädällä, mitä niillä rahoilla tekisi. Toisesta ovesta menee sellaista, mikä on ammattitaitoista, ja toisesta ovesta haalitaan sisään opetusohjelmia ja opettajia. Mieletöntä! Ihmettelen, että koulutusorganisaatiot suostuvat tällaiseen nöyryyttävään hommaan.

\section{URPO KALLIO}

Kyllä minä olen kokenut asian aivan eri tavalla. Nuorten joukossa on syntymässä sukupolvi, joka vieraantuu tyystin työelämästä, mutta jolle voitaisiin luoda ainakin ammatillisissa oppilaitoksissa uusia valmiuksia kohentamalla heidän

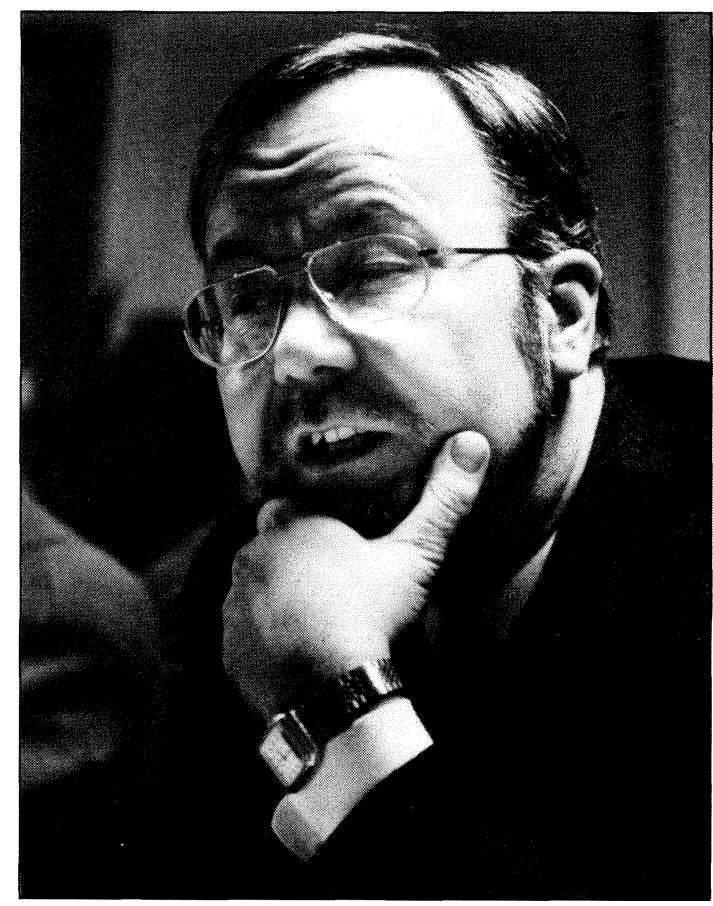

Simo Susiluoto 


\section{JYRKI HAIKOSEN KULTAJYVÄ}

Suomalaisten itsetunnon nostaminen. Olemme kansakuntana tulleet hiljattain alas Euroopan ostajan kuvitellusta asemastamme ja todenneet, ettemme olekaan niin hieno kansakunta, kuin ehdimme luulla. Koulutus on ehdottomasti väline itsetuntoon ja siinä meillä suomalaisilla on hyvät asemat.

Itsetunto liittyy myös aikaisemmin mainittuun sosiaaliseen kyvykkyyteen. Jos ei ole itsetuntoa, ei juuri sosiaalista kyvykkyyttäkään.

\section{PERTTI TIMOSEN KULTAJYVÄ}

Korvet ja korvien välit! Koulutus on korvien välissä ja siinä on meidän suomalaisten valtti.

Jos viran puolesta kehuisin kansalais- ja työväenopistojen rakennetta, niin sehän on koko maan kattava koulutusjärjestelmä ja sellaisena erittäin joustava. Minusta se on eurokunnossa ja sitä voisi myydä aivan hyvin muillekin valtioille. On aika surku, että sitä tuhotaan tässä lamassa rakentamatta mitään tilalle.

\section{SIMO SUSILUODON KULTAJYVÄ}

Koulutuksen pitkäjänteinen suunnittelu. Voin sanoa aivan konkreettisen esimerkin. Tässä suhdannevaiheessa, kun noususuhdanne on lähdössä käyntiin ja aikuiskoulutuskeskusten opettajien työsuhteet ovat muutaman kuukauden mittaisia, hyvät opettajat lähtevät parvena paremmille apajille. Parhaat siis kysytään meiltä pois ja jäljelle jäävät huonoimmat. Edessä on todella iso koulutustason lasku. Nään mahdollisuuden tarjota pitkäjänteisemmin työtilaisuuksia meidän elämän ja kuoleman kysymyksenä.

Minusta kilpailuttaminen tai markkinavoimien mukaantulo on koulutuksen suunnittelun elementtinä ihan oikein, koska se vie löysät pois. Mutta siltä kannalta se on hemmetin huono juttu, että koulutustarjonta on vailla suuntaa eikä se koskaan pysty kulkemaan elinkeinoelämän kehityksen mukana, siis elinkeinoelämää kehittävänä elementtinä.

Pitkäjänteisyys ja pitkän tähtäimen koulutuksen suunnittelu - ne näen välttämättöminä.

\section{URPO KALLION KULTAJYVÄ}

Koulutuksen joustavuus. Pysyvä epävarmuus on tulevaisuuden yhteiskunnan pysyvä piirre. Tulevaisuutta ei varmaan pystytä ennustamaan sen paremmin kuin tähänkään asti. Sen vuoksi koulutusjärjestelmän tulisi hyvin nopeasti ja joustavasti kohdata muutokset ja auttaa ihmisiä, oli kysymyksessä sitten elinkeinoelämässä tapahtuvat muutokset, yksityisten ihmisten ammattiuralla tapahtuvat muutokset tai ylipäätään elämäntilanteen muuttuminen.

Haluaisin myös, että aikuiskoulutuksessa voitaisiin siirtyä järjestelmä- ja organisaatiokeskeisestä ajattelusta oppimis- ja oppijakeskeiseen ajatteluun. Lähdettäisiin siis aika tavalla tarvitsijan, käyttäjän yksilöllisistä lähtökohdista ja elämäntilanteista, ja kiinnitettäisiin huomiota siltä kannalta koulutuksen joustavaan järjestämiseen.

\section{TARJA KOSKELAN KULTAJYVÄ}

Koulutuksen pitäisi antaa ihmisille niitä valmiuksia, joita avoimessa yhteiskunnassa tarvitaan. Minäkin sanon käytännön esimerkin. Jos elinkeinoelämässä menee huonosti, se heijastuu suoraan julkiselle puolelle, joko verotulojen vähenemisenä tai ylipäätään muuten elintason laskuna. Emmehän elä missään suljetussa systeemissä. Eikä meillä ole mitään yksityistä tai julkista sektoria, vaan kansantalous. Sen vuoksi en näe ristiriitaa jonkun "mörkö"-markkinavoimien ja "pyhän" julkisen koulutusjärjestelmän välillä.

Jos aikuiskoulutuksella ei pystytä luomaan ihmisiin uskoa ja antamaan käytännön välineitä muutoksen ymmärtämiseen ja siinä mukanaoloon, ollaan hukassa. Mielestäni tässä suhteessa aikuiskoulutusorganisaatiot yrittävät tehdä tosissaan töitä.

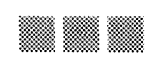

Keskustelun koonnut:

ANNELI KAJANTO

Kuvat:

KALEVI KESKI-KORHONEN 